\section{CASE STUDY: WEIGHT LOSS CAUSES IMPROVEMENT IN METABOLIC SYNDROME AND COST EFFECTIVE}

\section{ABSTRACT}

A case report study conducted in a tertiary care hospital to determine the effectiveness of supervised exercise diet plan along with behavioral therapy to reduce weight in the metabolic syndrome. A 54 years old obese male was
selected to conduct the study that suffering from diabetes for last 10 years hypertensive previous 13 years, knee osteoarthritis previous 8 years back and also has complaint of dyspnea as a result facing severe problems in his ADL. He was on 8 different medications when he visited a Physiotherapy OPD in a tertiar
care hospital by his consultant to secure his health status. He was than enrolled in fitness program to reduce weight under supervision of a physical therapist. According to his lab reports he was highly on health risk and was going in severe depression due to the difficulty facing in his daily life. The out measures of our
study was Visual Analogue scale. Exercise and diet plan with counseling sessions, after 16 weeks supervised exercise diet plan and counseling sessions ijid profile and hypertension. The patient was following exercise plan for 5days/week and diet plan throughout the month with a single counseling session in a week with marked reduction in medications. Our study concludes that medically supenised weight-loss program facilitates is safe and tions.
Muhammad Sarfraz Ziauddin College of Physical Therapy Zlaudain University

Erum Naz

Ziauddin College of Physical Therapy Ziauddin University

rafahad@yahoo.com

Arham Shamsi

therapist

M.S Hospita

arhamshamsi@yahoo.com

Syeda Amool Sakeena Rizvi

Lecturer

Ziuddin College of Physical Therapy

Ziauddin University
sakeenarizvi5@gmail.com

Dr. Rubina Kanwal

Incharge
Ahmed's Healing Hands

Roomi llyas

Physiotherapist
Self Employed

Self Employed
physioroomi@yahoo.com

Sarrraz M, Naz E, Shamsi A, Rizvi SAS Improvement in Meight Loss causes Syndrome and cost effective: Case Study. Pak. j. rehabil. 2013:2(2):45-47]

\section{INTRODUCTION}

Overweight and obesity are defined as abnormal or which can be measure by body mass index (BMIll whealth can be calculated by dividing a person's weight (in kilograms) by the square of his or her height (in meters). A person with a BMl of 30 or more is generally considere considered oven whight23. Ovenweight / obesity han 25 risk factors for a number of chronic diseases, including DM, cardiopulmonary, cardiovascular diseases and cancer'. Obesity is not only affecting elders but World Ic is also becoming a challenging issue in developing
countries like Pakistan6-8. Once obesity was considered as a problem of high income countries only but now overweight and obesity are dramatically on the rise in settings. In Pakistan the prevalence of obesity is 10.3\%9.

Obesity has a strong relation with diabetes. In 2000 diabetes was the 6th leading cause of life loss, based on cause. This number undervalues the actual number because diabetes is likely underreported as the cause of death. In a survey conducted in 2002, 18.2 milion people diagnosed ${ }^{10}$.

\section{CASE STUDY}

Mr. A is an obese, 54 years old married man with 3 suffering from DM for last 10 years. He was diagnosed hypertensive in 2001 , type 2 diabetes in 2003 and bilater knee osteoand excessives. We hast a history or shortness of breath and excessive weight since long. On Visud which has made him compromised in terms of his daily activities.

He regarded his excess weight as a result of overeating oversized portions and an increased use of confectionarles and oily food. He has already tried a lot of things to reduce his weight like use of different weight reducing
pills, weight reducing belts, and diet plans but every pills, weight reducing be
attempt resulted fruitless.

Mr. A's, average expendifure on medications is around PKR 8,000 a month, according to him.

Now Doctor has advised him to supervise weight reducfion under the guidance of a physical therapist. Therefore, he has been placed on a 16 weeks medical supervi-
sion of weight loss plan at Physiotherapy department of Ziauddin Hospital (north campus). At the start of the supenised weight reduction program that is January 2012 , he has following anthropometric and laboratory eadings which were recorded as baseline impression st

- Height: 5 feet 8 inches/68 inches Weight: $134 \mathrm{~kg} / 294.8 \mathrm{lbs}$ BMl: $45 \mathrm{~kg} / \mathrm{m} 2$

Hemoglobin Alc (HbAlc): $7.2 \%$

Iriglycerides: $154 \mathrm{mg} / \mathrm{al}$ : 7.290

LDL cholesterol: $98 \mathrm{mg} / \mathrm{dl}$

HDL cholesterol: $34 \mathrm{mg} / \mathrm{d}$

Creatinine, Serum: $1.1 \mathrm{mg} / \mathrm{d}$

Blood pressure: $150 / 90 \mathrm{~mm} \mathrm{Hg}$
11. Blood pressure: $\quad 150 / 90 \mathrm{~mm} \mathrm{Hg}$
12. VAS (knee pain) : $8 / 10$

At the beginning of the 16 weeks program the patient was on following medications and supplements:

1. Losartan/hydrochlorothiazide $50 / 12.5 \mathrm{mg}$ twice
daily (HCTZ) daily (HCTZ) 2 Metoprolol extended release, $200 \mathrm{mg}$ 2. Maily/once a day

3. Verapamil SR: $240 \mathrm{mg}$ once a day
$\quad$ Glyburide: $5 \mathrm{mg}$ twice daily Glyburide/metform5/500mg twice daily

5. Pioglitazone: $45 \mathrm{mg}$ once a day Ursodiol: $300 \mathrm{mg}$ twice daily

\section{INTERVENTION}

In light of above readings $\mathrm{Mr}$. A was given a Plan consisted of 16 weeks supervised weight loss treatment, providing lifestyle education and modifications. This consisted of

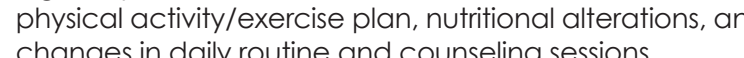

Exercise plan included aerobic workout for $30 \mathrm{~min}$ on recumbent bike al 00 RPM, muscle condifioning exercises (Pectoralis, Lattissmus Dorsii. Deltoid. Biceps. Triceps Quadriceps, Hamstrings, Calves, Rectus Abdominus and Erector Spinae) and stretching exercises.

Nutritional alterations consisted of $1200 \mathrm{kcal} /$ day includon high fiber diet to counteract constipation and to satisfy the hunger. Additionally, he was advised to take 4 Furthermore, 1 hour behavioral education/counseling
session per week was also included to maintain the motivation level.

\section{RESULT AND DISCUSSION}

In the case above, Mr. A needed to lower his blood glucose and AIC to help him lose weight. To achieve his portion sizes, and decrease his intake of fats, and sugars. Before starting the program, his blood glucose, blood pressure, and $\mathrm{AIC}$ were all above target range.

After the 16 weeks, he had lost $60 \mathrm{lbs} / 27.2 \mathrm{kgs}(134 \mathrm{~kg}$ to $\mathrm{kg} / \mathrm{m} 2$. His glucose levels improved from 170 to $130 \mathrm{mg} / \mathrm{dl}$ : his average blood pressure was enhanced from 150/90 to triglycerides. HDL and $\mathrm{DL}$ levels which becave 140,75 and $55 \mathrm{mg} / \mathrm{dl}$ respectively from 154,98 and $34 \mathrm{mg} / \mathrm{dll}$ respectively. Due to weight reduction and increase muscle endurance and strength the knee pain was scale.

As a result Mr. A was able to decrease the number and dosages of medications he was previously yaking. Over ride/metformin, metoprolol extended releasel were stopped completely and one was decreased by half (losartan/HCTZ). This netted a cost savings of PKR 4500 per month or PKR 54000 per year. His Losartan/HCIZ, 50/72.5 $\mathrm{mg}$, was decreased to once dally, Alc decreased 1.6 
medications were discontinued.

This weight-loss program mimics that, used in the successfil Diabeles Prevention Program with ongoing suppor is often regained after a weight-loss program and it coaching ends. A feature of the program used here is the availability of a maintenance phase including exercise

\begin{tabular}{|c|c|c|}
\hline $\begin{array}{c}\text { Anthropometrics } \\
\text { and Labs }\end{array}$ & $\begin{array}{c}\text { At Start of } \\
\text { Program }\end{array}$ & $\begin{array}{c}\text { At the End } \\
\text { Program }\end{array}$ \\
\hline Height & $\begin{array}{c}5 \text { feet } 8 \\
\text { inches }\end{array}$ & $\begin{array}{c}5 \text { feet } 8 \\
\text { inches }\end{array}$ \\
\hline Weight & $\begin{array}{c}134 \mathrm{~kg} / \\
294.81 \mathrm{bs}\end{array}$ & $\begin{array}{c}106.8 \mathrm{~kg} / 2 \\
34.9 \mathrm{lbs}\end{array}$ \\
\hline BMl & $45 \mathrm{~kg} / \mathrm{m}^{2}$ & $35.9 \mathrm{~kg} / \mathrm{m}^{2}$ \\
\hline Hemoglobin $A_{1 \mathrm{c}}$ & $7.2 \%$ & $5.6 \%$ \\
\hline Triglycerides & $154 \mathrm{mg} / \mathrm{dl}$ & $140 \mathrm{mg} / \mathrm{dl}$ \\
\hline Total cholesterol & $\begin{array}{c}200 \\
\mathrm{mg} / \mathrm{dl}\end{array}$ & $170 \mathrm{mg} / \mathrm{dl}$ \\
\hline LDL cholesterol & $98 \mathrm{mg} / \mathrm{dl}$ & $75 \mathrm{mg} / \mathrm{dl}$ \\
\hline HDL cholesterol & $34 \mathrm{mg} / \mathrm{dl}$ & $55 \mathrm{mg} / \mathrm{dl}$ \\
\hline Creatinine, serum & $1.1 \mathrm{mg} / \mathrm{dl}$ & $1.0 \mathrm{mg} / \mathrm{dl}$ \\
\hline Glucose, random & 170 & $130 \mathrm{mg} / \mathrm{dl}$ \\
\hline Bg/dl & $150 / 90$ & $\begin{array}{c}140 / 80 \\
\mathrm{~mm} \mathrm{Hg}\end{array}$ \\
\hline Blood pressure & $\begin{array}{c}150 / 90 \\
\mathrm{~mm} \mathrm{Hg}\end{array}$ & 6 \\
\hline VAS (knee pain) & 8 & \\
\hline
\end{tabular}

\section{CONCLUSION}

As this case demonstrates, weight loss brings many benereduction of medical care. Medically supervised weight-loss programs facilitate safe and effective weigh to follow patients and ensure their participation in mainte nance programs.

\section{REFERENCES}

[1] Hoeger WK. lifetime physical fitness and wellness. Hoeger WK, Hoeger A. Principal and labs for fitness and wellness. 6th Ed. USA: Wadsworth; 2010.202-05. Anspaugh JD, Hapdick HM, Rosalo Dr. Welliness concepts and applications.

[4] Gupta DK, Shah P, Mishra A, Bharadwaj S, Gulati S, Gupta $N$ et al. Secular trends in prevalence of Asian Indian adolescents aged 14-17 years. JPMC 2011;6(2):172-21.

Frayling MT, Timpson NJ, Weedon MM. A Common Variant in the FTO Gene is Associated with Body Mass Index and Predisposes to

b] Mushtaq MU, Gull S, Abdullah HM, Shahid U, Shad MA, Akram J. Prevalence and socioeconomic correlates of overweight and obesity among Health 2011;11:724. Q] Qidwai W, Ashfaq T. Imminent Epidemic of Diabetes
Mellitus in Pakistan: Issues and Challenges for Health Chopra M, Galbraith S, Darnton-Hill I. A global response to a global problem: the epidemic of over nutrition. Bull World Health Organ 2002;80(12):952-958.

[9] Jaffer TH. Prevalence of overweight and obesity tes mellitus in an Indo-Asian population. CMAJ 2006; 175(9):1071-1077.

[10] National Diabetes Statistics. last updated: 2011 December 6, cited 2012 December 16 Available at: index.aspx

\section{PAKISTAN JOURNAL OF REHABILITATION}

\section{INFORMATION FOR AUTHORS}

Guidelines

Submission of the articles will precede through emails sent to the Editorial Front Office. Before submission of an article ensure that the work described has not been published previously in any academic journal globally, in any language. The publication should be approved by all authors and similar work cannot be accepted in any form withou the writien consent of the

Pakistan Journal of Rehabilitation invites articles in the following categories:

Research Reports, Case Reports, Technical Reports, Meta-Analyses and Systematic Reviews, and Letters to the Editor (Details of these categories are given below).

For any queries kindly send emails to the Editorial Front Office:

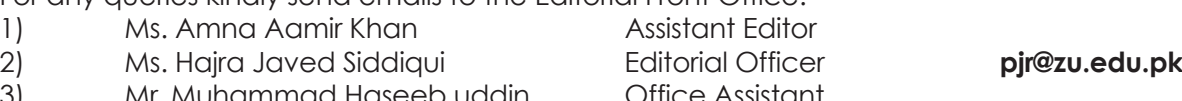

\section{Guidelines for Submission}

1) Authorship

f authors have made substantial contributions in:

Formulating and designing the study

- Collection, analysis or interpretation of the data

Changes to Authorsh

Juthe names of any author. written consent from all the authors should be sent to the Editorial Board. Also make sure that the reason of adding or deleting should be clearly mentioned with the email sent. The article should be unique, innovative and origina

mes the following categories of articles:

- Research Reports:

the rerts can be Clinical Trials, Diagnostic Studies, Observational and Prognostic Studies (Cohort, Case Control, Cross-Sectionall) or Qualitative Studies. The research reports aim for minimum 2500 words excluding abstrac and referencing with a range of 25-40 references.

- Case Reports:
Case reports aim for 750-1000 words excluding the abstract and referencing with a maximum limit of 10 references.

- Technical Reports:

Technical reports are also appreciated in the journal, aiming for 1000-2000 words excluding the abstract and 5-20 references.

- Meta-Analyses and Systematic Reviews:

for minimum 3000 words, excluding the abstract and referencing with Checklist is preferred if applicable.

- Letters to the Editor

Letters to the editor aim for 250-500 words, with a maximum limit of 10 references. Current as well as contentious issues are appreciated in the journal.

4) Presentation of Manuscript

- The text should be written in either American or British English, but a mixture is not acceptable.

- Font Style 'Colibri' with the text font size ' '12' ' is acceptable

- The font size of the heading should be ' 16 ' and the subheadings should be ' 14 '.

- On the main page the abstract should be clearly indicated.

"The line spacing 1.0 shoula be used and cle clin the jage number.

- Avoid the repetition of words.

- Augmentation should precede the abbreviation initially. 